DOI: $10.17516 / 1997-1370-0754$

УДК 343.98

\title{
Innovative Approaches to Criminalistics
}

\author{
Marina V. Savel'eva, Aleksandr B. Smushkin \\ and Natalia L. Potapova* \\ Saratov State Law Academy \\ Saratov, Russian Federation
}

Received 09.05.2020, received in revised form 30.04.2021, accepted 11.05.2021

\begin{abstract}
In this scientific study, the authors made attempts to consider the current problems of criminalistics caused by the features of modern crime and highlighted modern innovative approaches to the detection and investigation of crimes. There is a trend in the evolution of crime, which determines the need for new modern criminalistics innovations, as well as new approaches to training investigative officers. The article uses proven methods of scientific analysis. The authors analyse the views of leading experts on the main areas and trends of innovative development of Russian criminalistics. The authors justify the need for simultaneous development of material innovations (new technologies), ideal innovations (new theories, concepts, recommendations) and the most innovation-oriented subject of law enforcement. The results of the research can be used in research and forensic activities, as well as in teaching criminalistics and related courses in higher and secondary specialized educational institutions of legal profile.
\end{abstract}

Keywords: innovations in criminalistics, the evolution of modern crime, technologizing forensic activities, training of employees of law-enforcement agencies, digital technology in criminalistics.

Research area: law.

Citation: Savel'eva, M.V., Smushkin, A.B., Potapova, N.L. (2021). Innovative approaches to criminalistics. J. Sib. Fed. Univ. Humanit. Soc. Sci., 14(5), 718-723. DOI: 10.17516/1997-1370-0754.

(C) Siberian Federal University. All rights reserved

* Corresponding author E-mail address:m300kk64@mail.ru, skif32@yandex.ru, potapowa.nataliya2013@yandex.ru ORCID: 0000-0003-1619-8325 (Smushkin); 0000-0003-2655-1233 (Savel'eva); 0000-0002-8717-6898 (Potapova) 


\title{
Инновационные подходы в криминалистике
}

\author{
М.В. Савельева, А.Б. Смушкин, Н.Л. Потапова \\ Саратовская государственная юридическая академия \\ Российская Федерачия, Саратов
}

\begin{abstract}
Аннотация. В данном научном исследовании предприняты попытки рассмотреть обусловленные характеристиками современной преступности актуальные задачи криминалистики, выделены современные инновационные подходы к раскрытию и расследованию преступлений. Отмечена тенденция эволюции преступности, предопределяющая необходимость и новых современных криминалистических инноваций, и новых подходов в подготовке сотрудников следственных органов. Авторами обоснована необходимость одновременного развития материальных инноваций (новой техники), идеальных инноваций (новых теорий, концепций, рекомендаций) и самого инновационно-ориентированного субъекта правоприменения.
\end{abstract}

Ключевые слова: криминновации, эволюция современной преступности, технологизация криминалистической деятельности, обучение сотрудников правоохранительных органов, техникознание, цифровые технологии в криминалистике.

Научная специальность: 12.00 .00 - юридические науки.

\section{Introduction}

Nowadays, scientists as well as practitioners indicate the unwillingness of law enforcement bodies to oppose advanced technologization of the criminal world.

\section{Statement of the problem}

Thus, in March 20, 2017 in the Government's report of the RF on the activities of the Prosecutor's Office for 2016 the Attorney General noted that there are problems with resistance to cybercrime. Yu. Chaika named the major ones in detection and investigation of crimes in the field of IT technologies:

- insufficient training of specialists;

- the lack of methodological and legislative practices in the disclosure of this type of threat;

- delayed response to attacks;

- the absence of classic scene of crime and worked off mechanisms in the investigation of cybercrime (General Prosecutor's Office..., 2017).

In addition to investigations of this category of crimes, insufficient criminalistic training illustrates the fact that investigators have noted the acute need of bringing forensic specialists in criminal proceedings.

A.V. Gusev's study reasonably stated the fact, that criminalistic experts are involved in the process of investigation almost constantly, and especially at the initial stage of the investigation. (This fact is illustrated by the results of law enforcement practitioners' survey. Thus, the survey by the investigators from the Russian Ministry of Internal Affairs showed that $50 \%$ of respondents believe that it is necessary to involve forensic experts in order to help at the initial stage of the investigation, $45 \%$ of respondents state that such assistance is in demand at all stages of the investigation. In particular, $68.6 \%$ of respondents who are investigators from the Investigative Committee of Russia indicate the need of criminalist assistance at the initial stage of the investigation, $28.4 \%$ use such help at all stages of pre-trial investigation.)

Analysing the demand of various specialists in the course of criminal proceedings, the following can be stated: in most cases, experts-criminalists are engaged to participate in the investigation at an initial stage, which is 
related to structural units of ESC Ministry of Internal Affairs (MIA) (Gusev, 2015).

There is a need of additional criminalistic knowledge. It is often determined not only by the complexity of the investigation, but also by the insufficiency of criminalistic knowledge of investigators and shortage of time to develop new forensic technical innovations.

In the context of "the scene of crime" existing at present, criminalistics should promote the permission of abovementioned problems, as their solution is connected with specific features of the criminalistics subject. In this regard, it is necessary to agree with the T.V. Averyanova, who marks that both the common theory of forensic examination and criminalistics are based on scientific and technological potential and innovative processes, transform common scientific and criminalistic ideas into the result that has practical application (Averyanova, 2015).

\section{Discussion}

Analysing innovative development of modern criminology, M.V. Zhizhina notes that it is advisable to highlight a few major areas. The first area is to use innovative materials, as well as development and implementation of new technologies and solutions. The second area is related to implementation of innovative technologies in various investigative proceedings (According to M.V. Zhizhina, as for the second area, it is being actively implemented particularly to conduct in-situ investigations. We believe that it is necessary to look deeper into this problem. In most cases this innovative area is evident in the emergence of new investigation actions and modification of existing rules, for example, removing information from the technical communication channels, getting information about the connection between subscribers, an important component of which is the billing information and geolocation, that is, there is opportunity to find out where the subscriber of interest was at the time of conversation. This investigative activity as a source of relevant information was previously not available and, therefore, is not regulated by the law. But with the advent of technical possibilities they actively began to be implemented in criminalistic practice).

The third area is seen by the author in an active implementation of information technologies in the sphere of law enforcement activities.

But at the same time, M.V. Zhizhina highlighting three areas, believes that the mentioned directions of the development of innovations in criminalistics do not deplete the full potential of innovative technologies in forensic purposes. The author assumes that the development and implementation of criminalistic innovation products is being worked out along different lines of investigations and pre-trial proceedings (Zhizhina, 2012).

A more holistic approach, in comparison with the point of view of M.V. Zhizhina, has been marked by N.B. Nechaeva, who holds to the idea of separating forensic innovations into two types. The first systematic type of innovative products in criminalistics proposed by M.V. Zhizhina is related to innovation strategy, policy, as well as new approaches. The second group is presented by reforming the existing processes, techniques in which one can automate separate operations. Innovative processes both in criminalistics science and at a practical level go hand in hand with the organization of investigating crimes (Nechaeva N.B., 2013). In this article we illustrate this problem in details.

Many criminalistics scientists emphasized the direct link of scientific and technical progress using criminalistic knowledge. The effect of informatization of modern society is the technologization of criminalistics. The newest information and digital technology are actively implemented and developed. These new "tools" are used extensively by criminalistics in all its sections. New investigative techniques and other algorithms for solving tactical problems and other problems of law-enforcement activity appear. It is deemed that in the new context criminalistics should expand a range of studied traces besides the traditional ones and devote substantial attention to new types of traces: computer, electronic, sonic, video traces, etc.) (Aleksandrov, 2015; Levchenko, Kutuzov, 2011).

In this connection, we should mention an interesting idea expressed by I.P. Ishchenko, 
who highlighted the necessity to develop virtual space by criminalistics. Thus, it is directly related to embodying new technologies and using them, as well as the computerization of law enforcement activity (Ishchenko, 2012).

In modern conditions the intellectualization of crime and the informatization of society leads to a partial retreat into the past or committing classic crimes: theft, fraud, murder, cheating by other ways. First of all, it should start with qualifying different crimes. Meanwhile, using modern criminalistic innovative technologies unsolved crimes of the past can be successfully investigated and discovered.

Positive results of investigations can be used as examples. These examples are described in the article by A.I. Bastrykin "About the secret technology to investigate unsolved crimes" (Bastrykin, 2016). However, in this article the list of criminalistic tools responding to the needs of modern criminal activities is not exhaustive. For objective reasons (including specificity of mentioned DSP information and due to the limited number of articles), many modern innovative technological tools that improve the efficiency of the investigation remained undiscovered. These technical means perceptibly differ by their methods of the organization and intellectual-technical parameters from the ones that were available earlier. Their principles can relate as well to innovative ones (Nechaeva, 2013).

The main criminalist innovations enabling to reach the decision of universal tasks at present are:

- the use of nonlethal weapon of various methods of impact (sound, electroshock, laser, microwave) with a view of prevention of crimes and mass disorders, as well as implementation of the intruders' detention.

As the example of this innovation it is possible to name Acoustic Device of Distant Action ("Long Range Acoustic Device"), which is sometimes referred to as "sound or acoustic gun" nonlethal weapon of deterrent action developed by American Technology Corporation. (Kusainov, Akhmetova, 2012);

- the use of intellectual video surveillance cameras to ensure implementation of surveillance and other investigative activities, as well as for the prevention of crimes;

- operation of unmanned aerial vehicles to protect the overall public order in the places with crowds of people, as well as in the preparation, organization and fixing the results of separate investigative actions (Moiseev, 2015; Moiseev, 2013; Denis Fedutinov, 2010);

- achievement of the monitoring of personal data of the paroled from prison, as well as suspects, to whom the preventive measure is applied without detention with the help of electronical tracking (Methodological Guidelines, 2013; Government of the Republic of Kazakhstan, 2012);

- the use of united systemic electronic means of searching and establishing the identity for investigation "hot pursuit" and prevention of offences (Yakovenko, 2005);

- realization of opportunities of information retrieval systems (a vivid example of this innovation in criminalistics is "Obraz ++", which contains information on providers of operational interest and allows searching individuals on personal data, facial image, photo-and isocomposite portraits, verbal description, subjective portrait) for detecting crime "hot pursuit";

- appliance of geo-information systems (Biruykov, 2009; Duseva, 2012) to provide information of analytical system of decision-making in crisis situations, to use type systems as Domain Awareness (DAS) to counter crime;

- the using of software intellectual type, for example "Blue Crush" systems, in order to deal with retrospective forecasting of the crime (Omelchenko, Akhmetzyanov, 2003);

- using mobile system and software products of the type Ufed Touch Ultimate in order to supplement the data base of the investigation (Burtseva, Rogova, 2014);

- creating specific complexes as XRY COMPLETE PINPOINT (Micro Systemation company), which are used to secure information against extraction and data against deletion from mobile devices (Averyanova, 2015);

- implementing the capacity of special psychological technologies of profiling (In criminalistic purposes profiling is usually understood as tools and techniques to 
prevent criminal events by identifying potential dangerous persons and criminogenic situations leading to criminal situations), using the methods of applied psychology) in order to predict criminal situations and prevent crimes, with the help of techniques of applied psychology (Enikolopov, Lee, 2007; Verenikina, 2017).

Beyond above-stated innovative technical and technological means of providing investigation and prevention of crimes, it is necessary to implement the control of technical means to prevent cybercrime. In particular, it is required for studying and applying by practitioners. In the conditions of changing legal sphere by legislator including the establishing digital environment regulated by law, it seems necessary to develop and use the appropriate means by law enforcement authorities and criminologists to simplify the procedure of investigating crimes through digital environment in accordance with the adoption of the Federal law "On amendment to parts 1,2 and 4 of the Civil Code of the Russian Federation (about digital rights)". By providing this, the law coming into force has given particular importance to the willingness of law enforcement officers to work with "electronic evidence". P.S. Pastukhov and V.V. Terekhin rightly noted that an indispensable condition for working with electronic evidence is to follow the forefront of technological progress as well as the ability to handle with them, getting rid of simply superficial understanding of IT technologies. Most of the judges, in their opinion, have very little knowledge how to use electronic evidence for proving certain facts of the case (Pastukhov, Terekhin, 2014).

\section{Results}

Summing up the research of problems and opportunities of using criminalistic innovations, the attention should be drawn to a number of particular moments.

Firstly, innovation processes in criminalistics are constant and rather active, but their implementation in practice of crime investigation is vicariously caused by interrelated factors: subjective (characteristics of a sufficient level of competence subject), economic (the ratio of goals and resources spent to reach them) and methodological (the need of using innovative products for best practices in criminalistics).

Secondly, there is a need for the adoption and implementation of educational multimedia-forensic process (Meretukov, Gusev, Danilyan, 2009), which would raise the learning process by forensics at a qualitatively different level. It is so necessary for the realization of innovations in criminalistics.

Thirdly, an important prerequisite for the realization of innovative processes is sufficient and qualified staff of innovative-oriented people, who are ready to take innovations in various fields of law-enforcement activity.

\section{References}

Aleksandrov, I.V. (2015). On Current Development Directions of Forensic Science. In Contemporary Forensic Science: Problems, Trends, Perspectives. Proceedings from the International Research and Training Conference, devoted to the 90 th anniversary of Prof. N.P. Yablokov. Moscow, December 22, 26 -28.

Averyanova, T.V. (2015). Innovation in Forensic Science and Forensic Examination. In Forensic Department. Expert Assessment of Criminal Proceedings. Expert Assessment (accessed June 10, 2019). Available at: www.expertugproc.ru/publ/averjanova_t_v/innovacii_v_kriminalistike_i_sudebnoj_ehkspertize/7-1-0-11

Bastrykin, A.I. (2016). On Secret Devices for Undetected Crime Investigation, In Rossiiskaia Gazeta. Federal Issue \#7104 (236) (accessed June 10, 2019). Available at: rg.ru/2016/10/18/bastrykin-rasskazal-o-sekretnoj-tehnike-dlia-rassledovaniia-prestuplenij.html

Biruykov, V.V. (2009). Geoinformation Technologies. Their Place in Information and Reference Support of Crime Investigation. In Scholary Notes of Tavrida National V.I. Vernadsky University. Series: Law Science 22 (61) - 2, 296-300.

Burtseva, E.V, Rogova I.A (2014). Problems Related to the Acquisition of Information Contained in Mobile Devices with the Help of Universal Forensic Extraction Device (UFED). In Forensic Science and 
Forensic Medicine (accessed June 10, 2019). Available at: http://www.rusnauka.com/13_EISN_2014/Pravo/11_165579.doc.htmDenis Fedutinov (2010). Special Purpose Air Drones. In Unmanned Aviation (accessed June 10, 2019). Available at: uav.ru/articles/spec_uav.pdf

Duseva, N.Y. (2012). Technical and Forensic Basics of the Use of Global Navigation System in Investigation and Prevention of Crime: PhD thesis (193 pages). Volgograd Academy of the Ministry of Internal Affairs of Russia.

Enikolopov, S.N., Lee, N.A. (2007). Psychological Peculiarities of Criminal Profiling. In Psychological Science and Education, 5, 295-299.

General Prosecutor's Office is Challenged by Cyber Crime. In Invest Foresight 20.03.17 (accessed June 10, 2019). Available at: if24.ru/kiberprestupleniya-i-genprokuratura/

Government of the Republic of Kazakhstan (2012). On Establishing the List of Electronic Tracking Instruments to Track Persons in Custody 2013 (accessed June 10, 2019). Available at: www.online. zakon.kz

Gusev, A.V. (2015). The Concept of Building Special Forensic Knowledge and Mechanisms in Criminal Proceedings Excluding Forensic Examination Aspect. Abstract from PhD Thesis. Krasnodar, 3-5.

Ishchenko, E.P. (2012). Perspective of Forensic Science Development as Related to Virtual Space. In Development Perspectives of Criminal Procedure Law and Forensic Science. (tribute to N.V. Radutnaya): proceedings from the $2^{\text {nd }}$ International Research and Training Conference. (Moscow, 11-12 April 2012). Moscow, Iurisprudentsiia Publishing House, 371-374.

Kusainov, D.Sh., Akhmetova, A.A. (2012). Perspectives of the Use of Electric Strikes by Law-Enforcement Officers of the Republic of Kazakhstan. In Topical Issues of Modern Science: Proceedings from the International Research and Training Conference. Karaganda, Karaganda Academy of the Ministry of Internal Affairs of the Republic of Kazakhstan, 219-223.

Levchenko, O.V., Kutuzov, V.I. (2011). On Innovative Techniques of Crime Investigation, In Vestnik of Orenburg State University, 3 (122), 70-73.

Meretukov, G.M., Gusev, A.V., Danilyan, S.A. (2009). Opportunities of Present-Day Interactive Forensic Training. In Journal of criminology, 3 (31), 63.

Methodological Guidelines (2013). The Use of Electronic Tracking Instruments by Law-Enforcement Authorities to Track Persons Released on Parole, Those Suspected of Crime Not Taken into Custody Including Those Under House Arrest. Karaganda, Karaganda Academy of the Ministry of Internal Affairs of the Republic of Kazakhstan.

Moiseev, V.S. (2013). Applied Theory of Air Drones Control: monograph. Kazan, Republican Centre for Education Quality Monitoring.

Moiseev, V.S. (2015). Basic Theory of Efficient Use of Air Drones: monograph. Kazan, Shkola Printing and Publications Centre.

Nechaeva, N.B. (2013). Innovations in Forensic Science. In Leningradskii Iuridicheskii Zhurnal, 2 (32), 156-162.

Omelchenko, V.A., Ahmetzyanov, M.L. (2003). The use of information technologies in the work of the expert units. In Information Technologies in Forensic Science (accessed June 10, 2019). Available at: libed.ru/konferencii-informatika/311694-1-informacionnie-tehnologii-kriminalistike-ispolzovanie-informacionnih-tehnologiy-rabote-ekspertnih-podrazdeleniya.php

Pastukhov, P.S., Terekhin, V.V. (2014). On the Concept and Essence of Electronic Evidence in Criminal Proceedings. In Vestnik of the Republican Komi Academy of State Service and Management. Series: State and Law, 18, 74 .

Verenikina, N.A. (2017). Profiling as the Means of Crime Detection and Investigation. In Topical Issues of the Russian Law, 9 (82), 203-208.

Yakovenko, I.N. (2005). Contemporary State and Perspectives of the Use of Information Technologies in Uncovering and Investigating Crime. Synopsis of PhD Thesis, Krasnodar, 17.

Zhizhina, M.V. (2012). Current Innovative Development of Forensic Science. In LEX RUSSICA (accessed June 10, 2019). Available at: lexrussica.ru/articles/article_218.html?issue=lexrussica-1-2012 